\section{Survival and Practice}

In haven't yet read the new book on the restoration profession, Ecological Restoration: Principles, Values, and Structure of an Emerging Profession, written by André Clewell and James Aronson and published in SER's Island Press Book Series, but the publication of Andy and James's book has led me to reflect on the development of the restoration field over the last 30 years. I know both the authors, who are long-time leaders in the field, but I am especially familiar with the career path of Andy Clewell, whose history, like my own, provides an interesting example of the diverse ways that people practice ecological restoration and how they become either volunteer or professional restoration practitioners.

I first met Andy in 1989 at the inaugural SER conference in Oakland, California. Later that year Andy and I traveled together on a Greenpeace mission to convince the Nicaraguan government not to salvage-log the entire Mosquito Coast following Hurricane Joan. A botanist by training, Andy had set up one of the first restoration practice firms in the U.S. after leaving a teaching position at Florida State University that he had held for 16 years. Throughout the 1990s, Andy and I had the opportunity to visit each other's projects and to discuss ideas about restoration practice and the challenges of making a living doing restoration. Since 2000, Andy and I have interacted as members of SER with the shared goal of seeing it become a truly international society. I fully expect Andy to continue hopping around the planet preaching the gospel of ecological restoration for years to come.

In thinking about the profession, it occurred to me that my own experience with restoration in some ways mirrors the diversity of the field. I have worked on restoration projects as a volunteer, as an employee of a government agency, as the owner of a for-profit restoration firm, as the director of a nonprofit conservation organization, and as a board member of SER. I have conducted restoration research, planned, implemented, monitored, and managed projects, and written about them (although not nearly enough!). From an ecological perspective I have worked on wetlands and uplands, forests and savannas. I've seen projects succeed beyond my wildest expectations and fail to the point of professional embarrassment. And I have seen great projects fall apart when interest waned or corporate interests shifted.

Ecological Restoration Vol. 26, No. 1, 2008

ISSN 1522-4740 E-ISSN 1543-4079

( 2008 by the Board of Regents of the University of Wisconsin System.
I believe it is the diversity of ways that people can approach and practice ecological restoration that makes it so powerful. For instance, Andy and I came to be restoration practitioners from two completely different angles. Andy already had a career as a university professor, which he gave up to become a restoration practitioner. I started doing restoration as a kid, before most people knew what to call it. Andy started his business focusing on restoring ecosystems from scratch on phosphate-mined lands. I came from a family of native plant growers, and started my own company planting native plants on eroded beaches and removing exotics in urban forest fragments. It is this fundamentally grassroots nature of restoration, open to people from so many walks of life, which attracts me.

When I look back at the 1980 s, I realize that running a restoration practice was a darn hard way to make a living. For many people, either there wasn't enough work to go around, or it was boom and bust. Getting our foot in the door was tough, and even when we did, we were often stepping into uncharted territory, developing new techniques as we went along and betting the farm that we could figure out how to do it. Only the very best survived with their initial business plan intact. As it should be, the rest of us had to adapt, sometimes doing things in a radically different way than we intended. Which is fine; it is good to be resilient.

Nowadays, there are so many ways to practice ecological restoration-literally thousands of volunteer opportunities, agency and non-profit positions, and university programs. But where is all this really heading? Will the practice of ecological restoration become so professionalized that opportunities for volunteerism disappear? Will small business owners be squeezed out by giant corporations? Will big academia shut out lesser research institutions? Let's face it, restoration is becoming big business. For instance, Storm Cunningham of the Revitalization Institute estimates that $\$ 1.5$ to $\$ 2$ trillion a year is invested in the "restorative development" of communities and natural systems. Big nonprofits, such as The Wilderness Society, are creating permanent positions like Forest Restoration Director.

Whatever happens with the profession, we need to keep the grassroots nature of ecological restoration intact. A balance must be struck that allows many people to participate and benefit. We need community restoration projects and we need small businesses practicing ecological restoration. We need a Global Restoration Network, but not the globalization of restoration. And we certainly don't need 
a Restoration Czar telling everyone what to do. We also need to be cognizant that more money will attract competitors from allied fields who will want to do our work, but not necessarily with the same standards, attention to detail, and motives.

As professional practitioners, the fundamental thing we have to do is survive. It is not enough to have ideas. We need a business plan and we need to adapt. But we also need principles, even if that means turning down work because a project runs counter to what we think is right. We can also learn a lot from each other about how to run a restoration business and how to better practice our craft. So for all you practitioners out there, read Ecological Restoration and join SER. Engage in conversation with your peers, young and old. Travel around, see what others are doing. Please don't stay in your own back yard.

Would Andy Clewell agree? I couldn't say. You'll just have to go out and read his book.

George Gann, Chair

Society for Ecological Restoration International

\section{A Special Issue of Ecological Restoration}

\section{CALL FOR SUBMISSIONS}

\section{What does Climate Change Mean for Ecological Restoration? \\ Editors, Mrill Ingram and Andrew Light}

Ecological Restoration is seeking submissions for a theme issue devoted to climate change and restoration. We welcome submissions reflecting the ecological and social implications of climate change for restoration science and practice, as well as policy, ethical, and technological considerations. Article topics might include:

- What does environmental change mean for the value of reference conditions in restoration practice?

- How are restoration managers setting goals in the context of natural "moving targets"?

- How well can current federal and state land management policies that support restoration respond to climate change?

- Will climate change alter our understanding and definition of invasive species?

- If, as is frequently argued, climate change underscores the dependence of human well-being on "ecological security," how can we assure that restoration efforts are informed by the needs of more vulnerable human populations?

- Metaphors of healing abound in the restoration literature. Yet climate change involves global-scale, unpredictable and perhaps permanent ecological shifts that may not be best understood as an affliction from which we can be healed. What metaphors will prove most effective for communicating to a larger audience about the need to restore ecosystems in the context of climate change?

Deadline for submissions: June 1, 2008. Please visit www.ecologicalrestoration.info for author guidelines. Email contributions to mingram@wisc.edu and include "climate change" in subject line. 